\title{
Lead and cadmium contents in selected macrofauna species from the Dogger Bank and the eastern North Sea
}

\author{
Ingrid Kröncke
}

\author{
Biologische Anstalt Helgoland (Zentrale); Notkestr. 31, D-2000 Hamburg 52 \\ and \\ Institut für Hydrobiologie and Fischereiwissenschaft; Zeiseweg 9, D-2000 Hamburg 50, \\ Federal Republic of Germany
}

\begin{abstract}
Lead and cadmium concentrations were measured in the polychaetes Nephtys hombergi and $N$. caeca, in the sea-urchin Echinocardium cordatum, and in the bivalve Venus striatula obtained from the Dogger Bank and the eastern North Sea. The cadmium concentrations determined in all four species from these areas were relatively equal, except for an increase in concentration found in those species from the northeastern part of the Dogger Bank. A lower lead content was generally observed in the individuals taken from the German Bight than in those from the Dogger Bank, especially from its northeastern part. In the case of lead, it is possible to divide the southern North Sea into three regions according to the different concentration levels by statistical treatment: the less contaminated German Bight, the more contaminated central Dogger Bank and the highly affected northeastern Dogger Bank. The results obtained contradict the prevailing opinion that offshore invertebrate populations are, in comparison to individuals from coastal regions, less affected by contaminants such as heavy metals.
\end{abstract}

\section{INTRODUCTION}

The input of pollutant loads into the North Sea is generally considered to derive from land-based sources via rivers, coastal waters and the atmosphere. For this reason, contamination studies have generally been conducted only in areas close to the waste sources. According to an environmental assessment of the North Sea (Umweltprobleme der Nordsee, 1980) the coastal waters act as contaminant sinks. For this reason, the central parts of the North Sea were believed to be to some extent unaffected. In 1985 and 1986, samples of macrofauna species such as polychaetes Nephtys hombergi, N. caeca (predators), the sea-urchin Echinocardium cordatum (deposit feeder) and the bivalve Venus striatula (suspension feeder) were taken to analyse their lead and cadmium content. These species were chosen because they represent different feeding types. In addition, they are distributed over the whole of the North Sea area. Thus, they can be used to detect regions of different contamination levels. The major region of investigation was the Dogger Bank, an offshore shallow-water area, approximately $300 \mathrm{~km}$ in extension. This study, concerned with the distribution of heavy metals in selected macrofauna 
species, is a contribution within an interdisciplinary research project dealing with the distribution and processes of contamination in the North Sea.

\section{MATERIAL AND METHODS}

\section{Sampling}

The sampling stations were located on the Dogger Bank and in the eastern North Sea (Figs 1-3). Sampling took place in October 1985 and July/August 1986. The samples were taken with a galvanized $0.2 \mathrm{~m}^{2}$ Van-Veen grab. They were then quickly washed through a sieve of plastic (frame) and stainless steel (mesh, mesh size $1 \mathrm{~mm}$ ). Undamaged live specimens were kept in running water for 2 days to let them empty their guts, and were stored frozen at $-20^{\circ} \mathrm{C}$ prior to analysis.

\section{Preparation of samples for heavy metal analyses}

The samples were thawed in a clean-bench. The specimens then underwent the following procedures: For Nephtys hombergi and $N$. caeca, the length classes $<5 \mathrm{~cm}$, $6-8 \mathrm{~cm}, 10-12 \mathrm{~cm}$ and $>12 \mathrm{~cm}$ were selected. For the length class $6-8 \mathrm{~cm}, 5$ individuals per station were pooled; for the length class $10-12 \mathrm{~cm}$ two individuals, for the remaining length classes $(<5 \mathrm{~cm}$ and $>12 \mathrm{~cm}$ ) all available specimens per station were pooled. The pooled samples were freeze dried, afterwards homogenized by pulverizing with a plastic stick, and an aliquot of about $100 \mathrm{mg}$ was used for analysis.

In order to prevent contamination, identification of each worm by stereomicroscope inspection was omitted. Randomly taken samples established that, in general, individuals of 6-8 cm length belong to the species $N$. hombergi, and individuals that measure more than $12 \mathrm{~cm}$ belong to the species $N$. caeca. To exclude the possibility of erraneous identification, the two species are considered as Nephtys spp.

For Echinocardium cordatum the length classes $1-5 \mathrm{~cm}$ were chosen. It was planned to take 4 individuals per length class and station but in case less were caught all available specimens were taken. Contrary to the procedure used for other species, the calcium skeleton of $E$. cordatum was taken for analysis. From each specimen a piece of about $20 \mathrm{~mm}^{2}$ from the mouth region of the calcium skeleton was broken off, the pieces were pooled and subsequently analysed.

For Venus striatula the soft parts of mainly 4 individuals per station, shell length $1-1.5 \mathrm{~cm}, 2-2.5 \mathrm{~cm}$ and $3-3.5 \mathrm{~cm}$, were used. The pooled soft parts were freeze dried and homogenized by pulverizing with a plastic stick. An aliquot of about $50 \mathrm{mg}$ was analysed.

For all species and stations 2 independent samples, treated identically, were analysed in order to evaluate analytical reproducibility.

\section{Analysis}

The analytical procedure applied involved sample decomposition with nitric acid in a closed system (pressure decomposition), solvent extraction with 1,5-diphenylthiocarbazone/toluene, back-extraction with diluted hydrochloric acid, followed by graphite furnace atomic absorption spectrometry. Further details are given by Harms $(1983,1985)$. 
The precision (coefficient of variation) for replicate samples was about $10 \%$. All blanks contained less than $10 \%$ of the lowest values determined in this study.

\section{Statistics}

In order to divide the area of investigation into regions of different contamination levels of organisms, exploratory data analysis after Tukey et al. (1977) was performed. For each metal, medians and quartiles were calculated per cruise and species. Stations with concentrations between median and upper quartile were designated + , above upper quartile ++ , stations with concentrations between median and lower quartile were marked with -, below lower quartile with - - Subareas of different contamination levels were determined by the distribution of the signs,,,+++--- . Preliminary analysis of differences between subareas was calculated by notched box and whisker plots (based on median, quartile and intervals surrounding the median) after McGill et al. (1978). If the notches of different subareas do not overlap, the subareas are significantly different at a $5 \%$ significance level.

For the determination of higher significance levels $(1 \%)$ between the subareas, the Kruskal-Wallis-test (Lienert, 1973) was used. Afterwards, a post hoc rank test after Dunn (Lienert, 1973) was performed to analyse significant differences $(\mathrm{a}=0.01$ ) between certain subareas.

\section{RESULTS}

\section{Distribution of lead and cadmium}

Nephtys spp.

Figures $1 \mathrm{a}$ and $1 \mathrm{~b}$ show the distribution pattern of lead concentrations in Nephtys spp. (6-8 cm), sampled in October 1985 and July/August 1986. The lead content in samples from the German Bight ranges between $0.6-0.8 \mathrm{mg} / \mathrm{kg}$ dry weight. It is lower than in the samples from the Dogger Bank and Danish Waters which displayed up to $5.6 \mathrm{mg} / \mathrm{kg}$ dry weight (Fig. 1a).

In July/August 1986, the lead concentration was about the same as in October 1985 (Fig. 1b). Unfortunately, no data for the eastern North Sea are available.

In October 1985, the concentration of cadmium in Nephtys spp. was uniform in the area of investigation (Fig. 1c). Generally, the values ranged between $1.3-2.4 \mathrm{mg} / \mathrm{kg} \mathrm{dry}$ weight.

In July/August 1986, the distribution of cadmium values in the animals from the Dogger Bank was the same as the year before (Fig. 1d).

\section{Echinocardium cordatum}

In October 1985, sampling of Echinocardium cordatum (4 cm in length) was not so successful as in July/August 1986. Values for individuals from the central Dogger Bank and the German Bight (Fig. 2a) could not be obtained.

In July/August 1986 (Fig. 2b), an evaluation of the lead data showed that organisms from the open sea were more highly contaminated by lead than those from the German Bight. The values varied between $17-68.5 \mathrm{mg} / \mathrm{kg}$ dry weight in Dogger Bank organisms 

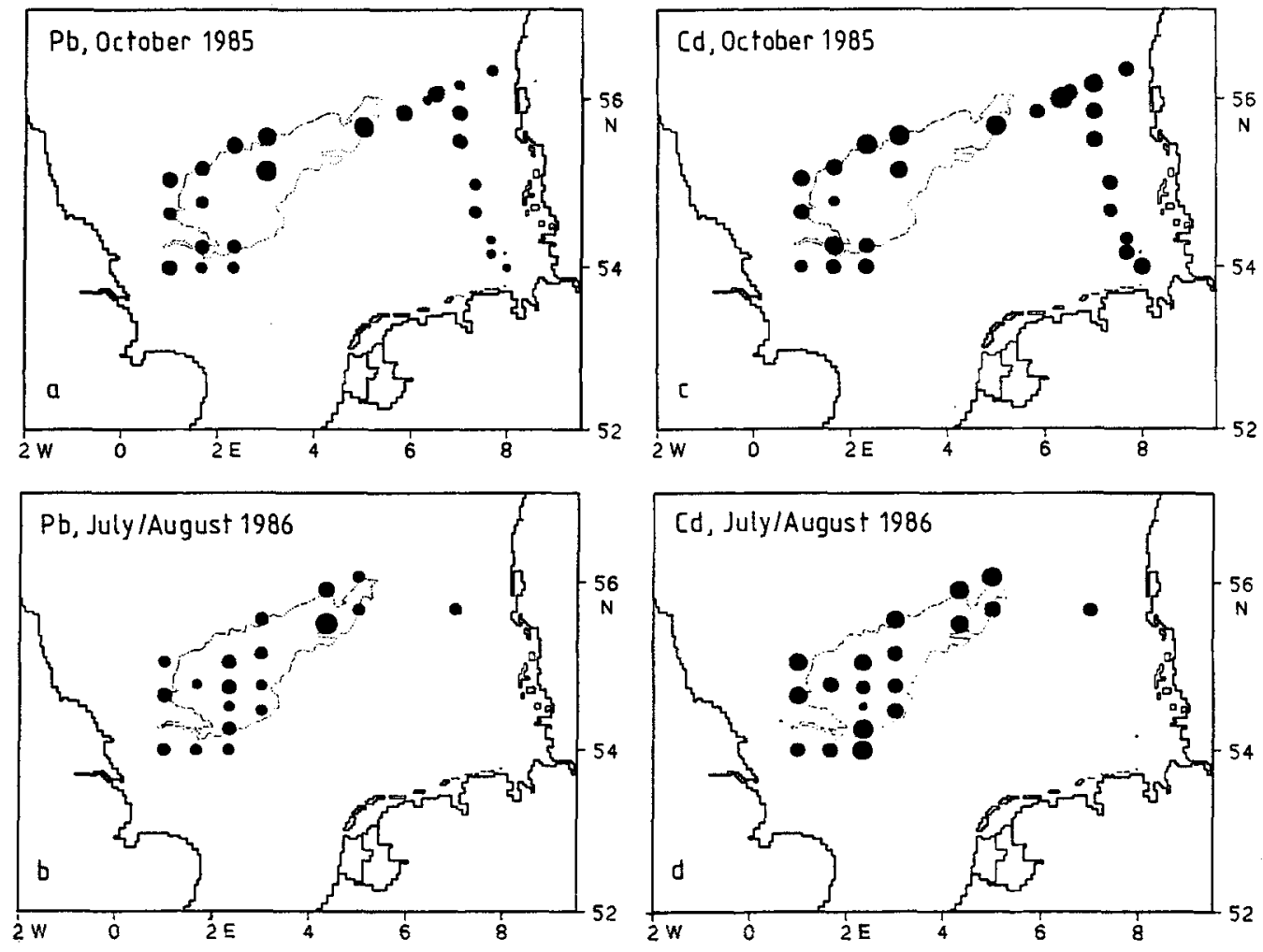

Pb:

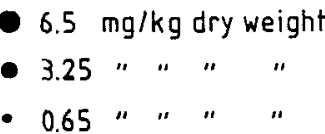

Co:

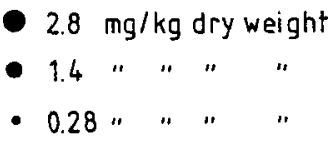

Fig. 1. Nephtys spp. Lead and cadmium concentrations (mg/kg dry weight) measured in October 1985 and July/August 1986. Location of Dogger Bank dotted in all maps

(maximum values in the northeastern part) and only $4.6-10.6 \mathrm{mg} / \mathrm{kg}$ dry weight in German Bight organisms.

The cadmium concentrations in October 1985 (Fig. 2c) and July/August 1986 (Fig. $2 \mathrm{~d}$ ) were uniform. The concentrations varied between $0.08-0.2 \mathrm{mg} / \mathrm{kg}$ dry weight. The only exception was in individuals from the northeastern part of the Dogger Bank with an increase in concentrations of up to $0.5 \mathrm{mg} / \mathrm{kg}$ dry weight.

\section{Venus striatula}

In October 1985 (Fig. 3a), the lead concentrations of $1.6-4.6 \mathrm{mg} / \mathrm{kg}$ dry weight in Venus striatula (3-3.5 cm shell length) from the German Bight were nearly as high as in those sampled at the two stations on the Dogger Bank with $3.3-4.4 \mathrm{mg} / \mathrm{kg}$ dry weight. Animals from stations in the northern German Bight and in Danish Waters revealed lower 

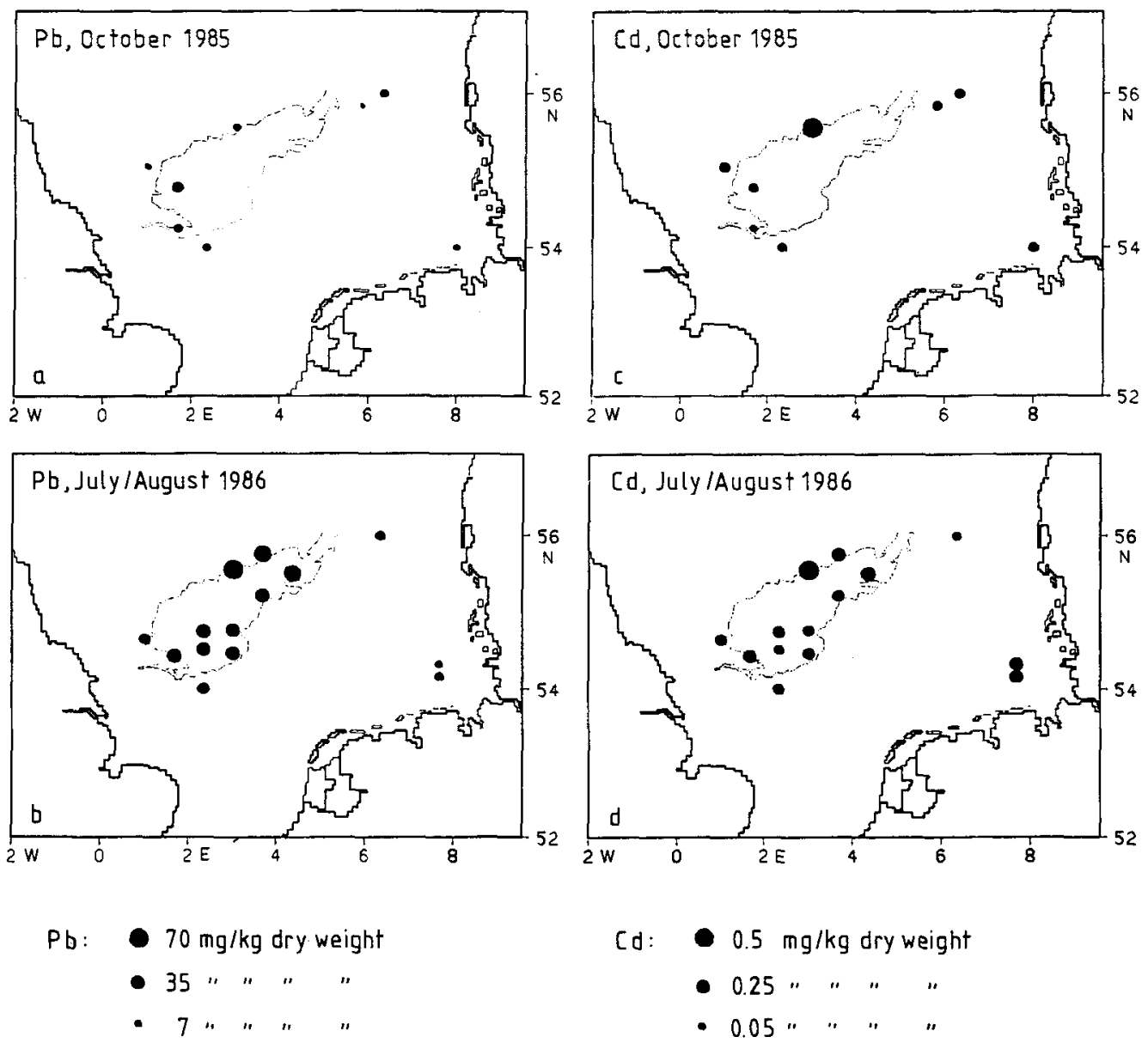

Fig. 2. Echinocardium cordatum. Lead and cadmium concentrations (mg/kg dry weight) measured in October 1985 and July/August 1986

contents (0.3-1.4 $\mathrm{mg} / \mathrm{kg}$ dry weight) than those from Dogger Bank stations. Figure $3 \mathrm{~b}$ shows the same situation for a few stations in July/August 1986.

The cadmium concentrations were uniform in individuals from the eastern North Sea in October 1985 (Fig. 3c). The values (0.8-2 mg/kg dry weight) were lower than those observed at the Dogger Bank stations $(3.2 \mathrm{mg} / \mathrm{kg}$ dry weight). In July/August 1986 (Fig. 3d), the situation seemed to be the same.

Ranged data, also for other length classes obtained during the present study, are summarized in Table 1. They are well in line with the above mentioned ones. Lengthdependent differences in concentrations were not observed. 

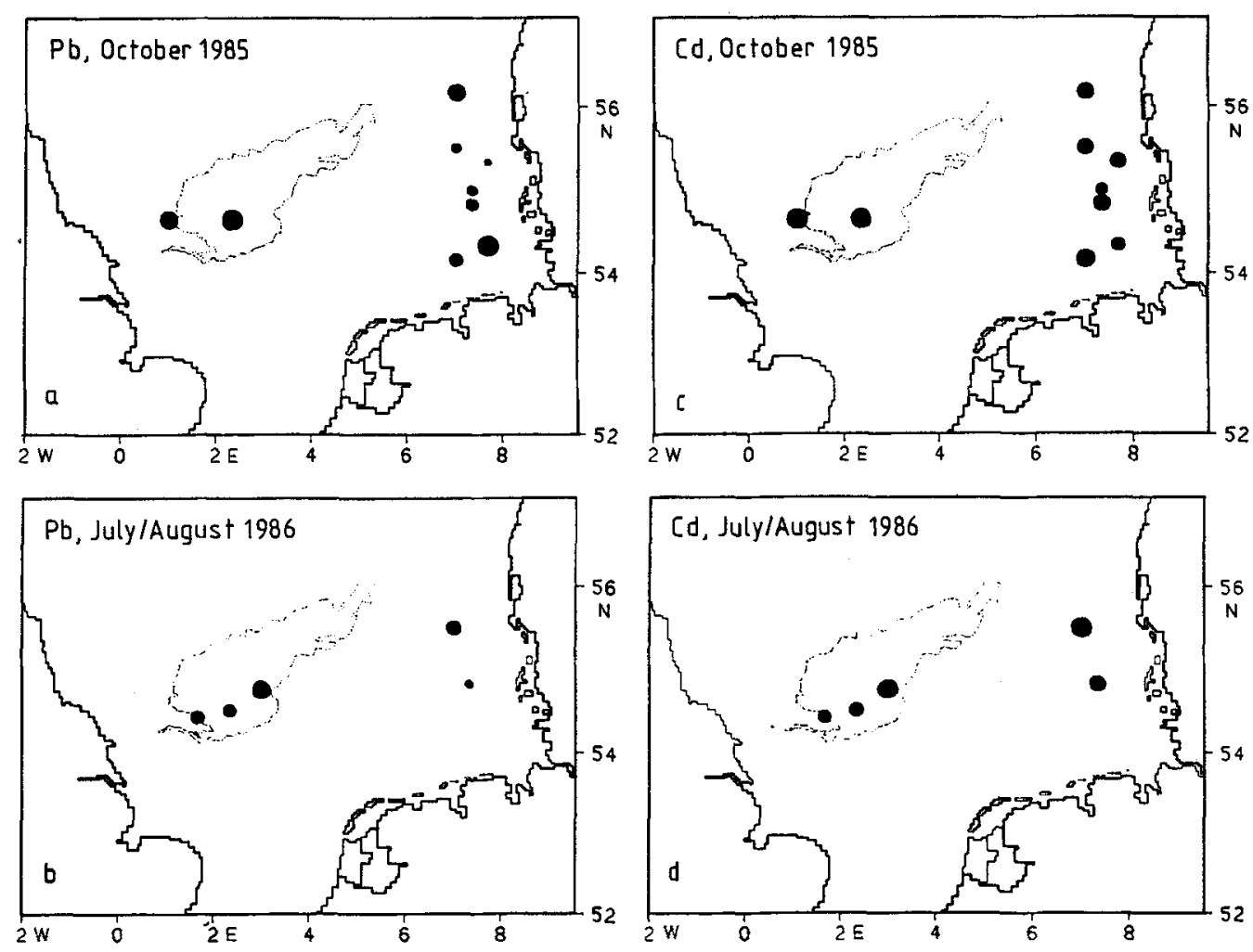

$\mathrm{Pb}:$

$-4.6 \mathrm{mg} / \mathrm{kg}$ dry weight
$-2.3 "$ " " " " " $"$

Co:

- $3.3 \mathrm{mg} / \mathrm{kg}$ dry weight
- $1.65 "$ " " " " "
- 0.33 "

Fig. 3. Venus striatula. Lead and cadmium concentrations (mg/kg dry weight) measured in October 1985 and July/August 1986

\section{Regional differences}

Significant differences $(a=0.01)$ in the contamination levels of macrofauna species from subareas of the southern North Sea were determined after Dunn (Lienert, 1973).

Attempts were made by statistical analysis to divide the southern North Sea into regions of different heavy metal levels as reflected by the contamination of macrofauna species. The data available for all size classes were used, since significant lengthdependent differences were not observed in the species investigated.

Nephtys spp.

In October 1985 and July/August 1986, significant differences in the lead content of Nephtys specimen from the German Bight (median $1 \mathrm{mg} / \mathrm{kg}$ dry weight: Fig. 4 a subarea 1), the northeastern Dogger Bank (median $3.4 \mathrm{mg} / \mathrm{kg}$ dry weight: subarea 2), and the 
Table 1. Ranges of lead and cadmium concentrations measured in Nephtys spp., Echinocardium cordatum and Venus striatula of different size classes

\begin{tabular}{|ccccc|}
\hline $\begin{array}{c}\text { Species/size } \\
\text { classes (cm) }\end{array}$ & $\begin{array}{c}\text { Pb (mg/kg d.w.) } \\
\text { October } \\
\text { 1985 }\end{array}$ & $\begin{array}{c}\text { July/August } \\
1986\end{array}$ & $\begin{array}{c}c \\
\text { October } \\
\text { (mg/kg d.w.) }\end{array}$ & $\begin{array}{c}\text { July/August } \\
1986\end{array}$ \\
\hline Nephtys spp. & & & & \\
5 & $2.1-5.6$ & $1.7-6.4$ & $1.2-2.3$ & $1.0-6.6$ \\
$6-8$ & $0.6-5.6$ & $1.0-6.5$ & $0.5-2.4$ & $0.2-2.3$ \\
$10-12$ & $0.5-5.4$ & $1.0-4.3$ & $0.5-3.2$ & $1.0-2.3$ \\
12 & $1.0-3.3$ & $1.2-7.8$ & $0.5-2.3$ & $0.3-1.5$ \\
Echinocardium cordatum & & & & \\
1 & - & $31.4-57.4$ & - & $0.09-0.5$ \\
2 & $4.4-12.4$ & $4.3-43.0$ & $0.09-0.4$ & $0.08-0.34$ \\
3 & $2.9-33.9$ & $5.9-30.0$ & $0.18-0.3$ & $0.12-0.18$ \\
4 & $1.8-18.6$ & $4.6-68.5$ & $0.04-0.5$ & $0.08-0.5$ \\
5 & $18.0-38.0$ & $17.3-46.7$ & $0.08-0.3$ & $0.13-0.2$ \\
Venus striatula & & & & \\
$1-1.5$ & $1.6-6.9$ & $0.8-2.0$ & $0.9-2.1$ & $0.8-1.1$ \\
$2-2.5$ & $0.6-7.1$ & $0.4-1.7$ & $0.8-3.6$ & $0.7-1.4$ \\
$3-3.5$ & $0.3-4.6$ & $0.5-3.5$ & $0.8-3.3$ & $1.0-2.8$ \\
\hline
\end{tabular}

central/southwestern Dogger Bank (median $2.1 \mathrm{mg} / \mathrm{kg}$ dry weight: subarea 3) could be noted. Organisms from the German Bight and northern Danish waters were uniformly contaminated (Fig. 4a). In July/August 1986, significant differences were noted between the values obtained on the northeastern (median $2.1 \mathrm{mg} / \mathrm{kg}$ dry weight: Fig. 4 a subarea 2) and central/southwestern Dogger Bank (median $1.6 \mathrm{mg} / \mathrm{kg}$ dry weight: subarea 3).

In October 1985, the cadmium content in organisms from the northeastern Dogger Bank (median $1.7 \mathrm{mg} / \mathrm{kg}$ dry weight: Fig. $4 \mathrm{~b}$ subarea 2) was significantly different from that observed in organisms from the central/southwestern Dogger Bank (median $1.2 \mathrm{mg}$ / $\mathrm{kg}$ dry weight: subarea 3). In July/August 1986, all values obtained for cadmium contamination in the macrofauna species studied were uniformly distributed (Fig. $4 \mathrm{~b}$ ).

\section{Echinocardium cordatum}

In July/August 1986 the lead contents of this species showed significant differences between the northeastern/central part of the Dogger Bank (median $34.7 \mathrm{mg} / \mathrm{kg}$ dry weight: Fig. 4c, subarea 2) and the southwestern part (median $17 \mathrm{mg} / \mathrm{kg}$ dry weight: subarea 3) as well as the German Bight (median $10.2 \mathrm{mg} / \mathrm{kg}$ dry weight: subarea 1).

Cadmium levels measured in sea urchins from the northeastern/central (median $0.3 \mathrm{mg} / \mathrm{kg}$ dry weight: Fig. 4d subarea 2) and southwestern Dogger Bank (median $0.1 \mathrm{mg} / \mathrm{kg}$ dry weight: subarea 3) showed significant variations in October 1985.

In Venus striatula significant differences in the lead content was noted only in October 1985 for individuals from the German Bight/southern Danish Waters (median $1 \mathrm{mg} / \mathrm{kg}$ dry weight: Fig. 4e, subarea 1) and northeastern Dogger Bank (median $4.2 \mathrm{mg} /$ $\mathrm{kg}$ dry weight: subarea 2). Cadmium concentrations were uniformly distributed in this species (Fig. 4f). 

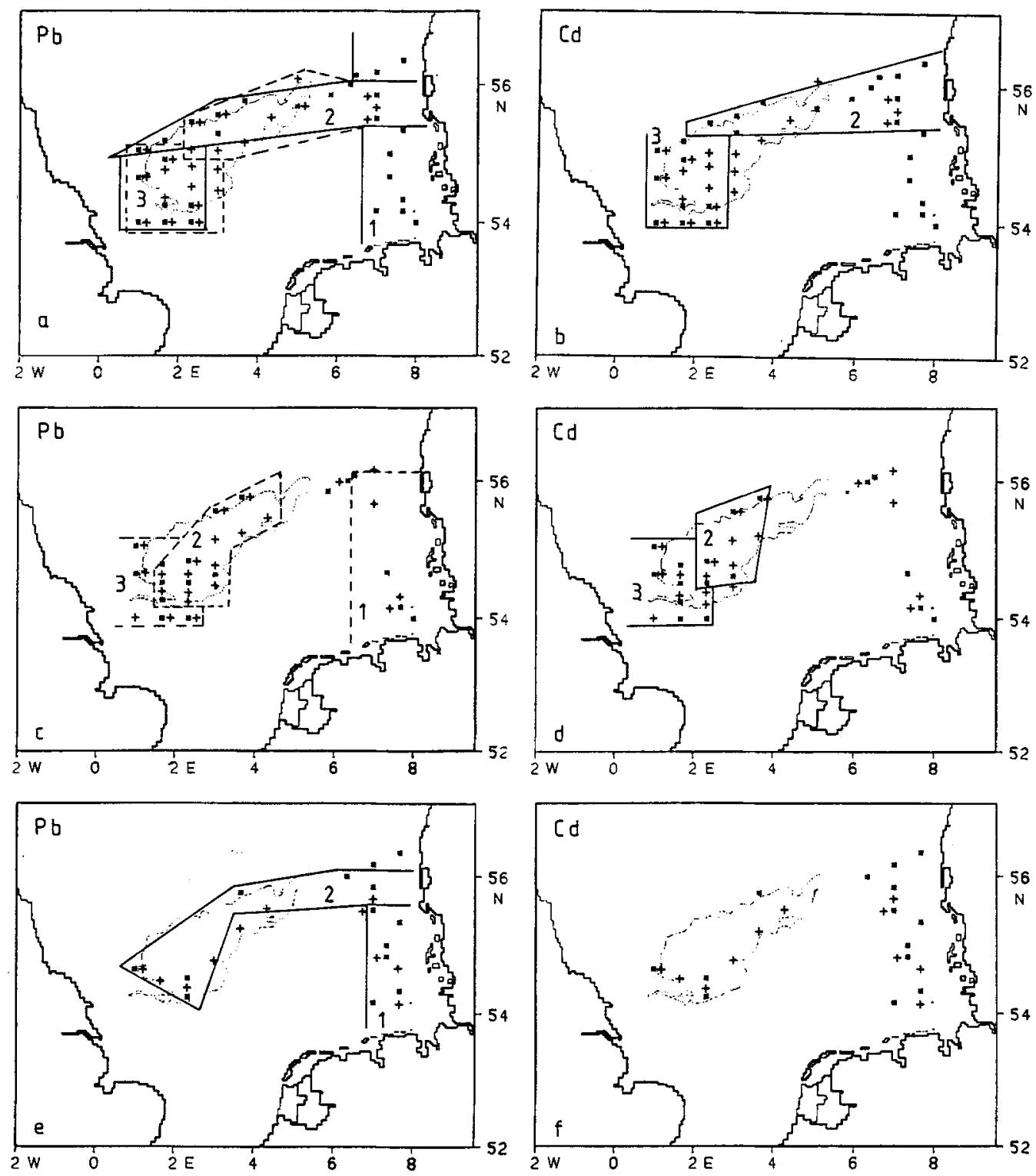

Fig. 4. Significant differences ( $1 \%$ level) in the lead and cadmium concentrations in Nephtys spp. $(a, b), E c h i n o c a r d i u m ~ c o r d a t u m ~(c, d)$ and Venus striatula $(e, f)$ from the delineated North Sea subareas in October $1985(-,-)$ and July/August $1986(+,--)$

\section{DISCUSSION}

For a long time the coastal waters of the North Sea were considered to act as contaminant sinks (Duinker \& Nolting, 1977, 1982). As late as 1984 Kremling et al. (1988) found for several dissolved trace metals, with the exception of cadmium, a decreasing 
gradient towards the open sea. The metal concentration in filtered sea water from the northeastern Dogger Bank was as high as that observed in the German Bight.

The results of this investigation into the distribution of lead and cadmium concentration in macrofauna species from the southern North Sea show that the prevailing opinion of a general decrease in contamination gradients from coastal waters to the high sea regions (Carlson, 1986) does not hold.

In general, it is safe to say that cadmium concentrations in the species Nephtys spp., Echinocardium cordatum and Venus striatula were relatively uniform in the whole area of investigation: that is, there was no gradient between coastal and open sea specimens (Figs 1, 2,3). However, an increase in the cadmium concentrations in Nephtys spp. and E. cordatum (Fig. 4b, d) from the northeastern part of the Dogger Bank compared to nearshore specimens was detected. Lead contamination of the macrofauna allows a division of the southern North Sea into areas of different contamination levels, the German Bight being less contaminated than Danish Waters/northeastern Dogger Bank and southwestern Dogger Bank (Fig. 4a, c, e). The northeastern Dogger Bank is also where lead is concerned a highly contaminated area.

Cadmium and lead concentrations in Nephtys spp. are similar to those measured in $N$. hombergi from highly contaminated British estuaries (Bryan et al., 1985), and in Nereis diversicolor from Danish coastal waters (National Agency of Environmental Protection, 1978). Cadmium values in $V$. striatula are similar to those analysed in different bivalve species by the afore-mentioned authors, while the lead contents observed in these species in this investigation were lower than those in comparative studies. The lead content found in the calcium skeleton of $E$. cordatum confirms often recorded results of investigations into the heavy lead contamination of bivalve shells (Fowler, 1985). Since Bryan (1976) and Bryan \& Hummerstone (1977) could show that contamination of polychaete species such as Nereis and Nephtys was correlated with the contamination of the surrounding sediments and considering the fact that the total sediments of the German Bight are more heavily contaminated by heavy metals than total sediments from the Dogger Bank (Kersten, 1988), the question arises as to why macrofauna species from the open sea are more contaminated than those from the German Bight.

An explanation of this apparent discrepancy is offered by the fact that even though the metal concentration in total sediments may be low, the fine fraction $(<20 \mu \mathrm{m})$ of surficial sediments is several times more highly contaminated in those areas where a high level of contamination was recorded in the organisms investigated (Irion \& Müller, 1987; Kersten \& Klatt, 1988). Since Brown (1986) could show that macrofaunal species prefer to feed on fine particles $<20 \mu \mathrm{m}$, it seems that the investigated macrofauna species representing three different feeding types (predator, deposit feeder and suspension feeder) were contaminated by the material ingested. This would explain how contaminants enter the food web. An additional reason for the higher contamination of offshore macrofauna populations might be that offshore species are older, even if they are of the same size as nearshore species, since, due to higher temperature and better food resources of coastal regions, nearshore specimens grow faster (Buchanan, 1966; Duineveld \& Jenness, 1984). In this case, the offshore organisms growing more slowly would have more time to accumulate the heavy metal at a given size. The organic matter found on the Dogger Bank consists mainly of highly oxidized terrestrial material (Wiesner et al., 1988) that offers hardly any nutritive value. Contents of organic carbon in total sediments 
of coastal regions consisting of planktonic material are higher and should further faster growth.

Lead and cadmium analyses of dab (Limanda limanda), which utilize the benthos as food resources, also show higher lead and cadmium concentrations in the offshore parts of the southern North Sea than in the German Bight (Claussen, 1988). An additional question in this context is whether the heavy metal concentrations analysed in this paper are responsible for the changes in macrofauna distribution on the Dogger Bank over the past 30 years (Kröncke, 1988).

These investigations show that it is necessary to intensify relevant studies throughout the North Sea to reach a better evaluation of the pathways of contaminants. The abovementioned results reflect a high cadmium input through the rivers Elbe and Humber and additional lead input via the atmosphere. Calculations of North Sea current systems by Hainbucher et al. (1986) indicate a wide transport of contaminants by the main currents from the British coast towards the southern North Sea to the Danish coast.

Acknowledgements. Thanks are due to Dr. U. Harms for hospitality in his laboratory and for interesting discussions on methods and results, and to Dr. H. Thiel and Dr. U. Harms for critically reading the manuscript. This paper is part of a doctoral thesis presented to the Faculty of Biology at Hamburg University. It was financed by the BMFT-research project "Biogeochemie und die Verteilung von Schwebstoffen in der Nordsee und ihr Bezug zur Fischereibiologie" (MFU 05438).

\section{LITERATURE CITED}

Brown, S. L., 1986. Feces of intertidal benthic invertebrates: influence of particle selection in feeding on trace element concentration. - Mar. Ecol. Prog. Ser. 28, 219-231.

Bryan, G. W., 1976. Some aspects of heavy metal tolerance in aquatic organisms. In: Effects of pollutants on aquatic organisms. Ed. by A. P. M. Lockwood. Cambridge Univ. Press, London, 2, 7-34.

Bryan, G. W. \& Hummerstone, L. G., 1977. Indicators of heavy metal contamination in the Looe estuary (Cornwall) with particular regard to silver and lead. - J. mar. biol. Ass. U. K. 57, 75-92.

Bryan, G. W., Langston, W. J., Hummerstone, L. G. \& Burt, G. R., 1985. A guide to the assessment of heavy metal contamination in estuaries using biological indicators. - Occ. Publ. mar. biol. Ass. U. K., 4, 1-92.

Buchanan, J. B., 1966. The biology of Echinocardium cordatum (Echinodermata: Spatangoidea) from different habitats. - J. mar. biol. Ass. U. K. 46, 97-114.

Carlson, H., 1986. (Ed.) Quality status of the North Sea. - Dt. hydrogr. Z. (Erg.-H. R.B), 16, 1-424.

Claussen, T., 1988. Characteristic levels and spatial distribution of trace metals in flatfish (dab, Limanda limanda) from the German Bight and the southern North Sea. - Mitt. geol.-paläont. Inst., Hamburg (in press.).

Duineveld, G. C. A. \& Jenness, M. I., 1984. Differences in growth rates of the sea urchin Echinocardium cordatum as estimated by the parameter of the von Bertalanffy equation applied to skeletal rings. - Mar. Ecol. Prog. Ser. 19, 65-72.

Duinker, J. C. \& Nolting, R. F., 1977. Dissolved and particulate trace metals in the Rhine estuary and the Southern Bight. - Mar. Pollut. Bull. 8, 65-71.

Duinker, J. C. \& Nolting, R. F., 1982. Dissolved copper, zinc and cadmium in the Southern Bight of the North Sea. - Mar. Pollut. Bull. 13, 93-96.

Fowler, S. W., 1985. Heavy metals and radionuclide transfer and transport by marine organisms. Symp. biol. Hungarica 29, 191-205.

Hainbucher, D., Backhaus, J. O. \& Pohlmann, T., 1986. Atlas of climatological and actual seasonal circulation patterns in the North Sea and adjacent shelf regions: 1969-1981. - Tech. Rep., Inst. Meeresk., Univ. Hamburg, 1-86, 1-201. 
Harms, U., 1983. Analytical procedures for the determination of copper, zinc, cadmium. lead and total mercury in organic material. - Baltic Sea envir. Proc. 12, 134-148.

Harms, U., 1985. Possibilities of improving the determination of extremely low lead concentrations in marine fish by graphite furnace atomic absorption spectrometry. - Fresenius $Z$. analyt. Chem $322,53-56$.

Irion, G. \& Müller, G., 1987. Heavy metals in surficial sediments of the North Sea. In: Heavy metals in the environment (International Conference, New Orleans 1987). Ed. by S. E. Lindberg \& T. C. Hutchinson. CEP Consultants Ltd., Edinburgh, 2, 38-41.

Kersten, M., 1988. Geological effects on the mobility of contaminants in marine sediments. In: Pollution of the North Sea: an assessment. Ed. by W. Salomons, B. Bayne \& E. Duursma. Springer, Berlin (in press.).

Kersten, M. \& Klatt, V., 1988. Trace metal inventory and geochemistry of the North Sea shelf sediments. - Mitt. geol.-paläont. Inst., Hamburg (in press.).

Kremling, K., Wenck, A. \& Pohl, C., 1988. Summer distribution of dissolved $\mathrm{Cd}, \mathrm{Cu}, \mathrm{Mn}$, and $\mathrm{Ni}$ in central North Sea waters. - Dt. hydrogr. Z. (in press.).

Kröncke, I., 1988. Macrofauna standing stock of the Dogger Bank. A comparison: I. 1951-1952 versus 1985. - Mitt. geol.-paläont. Inst., Hamburg (in press.).

Lienert, G. A., 1973. Verteilungsfreie Methoden in der Biostatistik. Hain, Meisenheim. 1, 1-736.

McGill, R., Tukey, J. W. \& Larsen, W. A., 1978. Variations of box plots. - Am. Statistn 32 (1), 12-16.

National Agency of Environmental Protection, 1978. Danish marine monitoring methods and data. Part II: The concentrations of selected heavy metals in bottom vegetation and bottom invertebrates. - Miljøstyrelsen, København, 103 pp.

Tukey, J. W., 1977. Exploratory data analyses. Addison-Wesley, Reading, Mass., 403 pp.

Umweltprobleme der Nordsee, 1980. Sondergutachten. Kohlhammer, Stuttgart, 503 pp.

Wiesner, M., Wirth, H. \& Haake, B., 1988. Organic faecies in surface sediments of the North Sea. Chem. Geol. (In press.). 